\title{
IDENTIFIKASI DAN UJI RESISTENSI BAKTERI PADA PASIEN ULKUS DIABETIKUM DI BANGSAL INTERNE RSUP DR. M. DJAMIL PADANG
}

\author{
Ringga Novelni ${ }^{1 *}$, Irwandi ${ }^{1}$, Diani Pratiwi ${ }^{1}$ \\ ${ }^{1 *}$ Sekolah Tinggi Farmasi Indonesia Yayasan Perintis Padang \\ e-mail: ringga.novelni@gmail.com
}

\begin{abstract}
ABSTRAK
Ulkus diabetikum adalah salah satu komplikasi kronis diabetes melitus berupa luka terbuka pada permukaan kulit yang dapat disertai adanya kematian jaringan. Kadar glukosa darah yang tinggi menjadi tempat strategis perkembangan bakteri. Penelitian ini bertujuan untuk mengetahui bakteri penyebab ulkus diabetikum dan resistensinya terhadap antibiotik. Jenis penelitian ini adalah Deskriptif Eksploratif. Pada penelitian ini didapatkan 10 sampel pasien ulkus diabetikum, 4 sampel Klebsiella pneumonia, 2 sampel Staphylococcus epidermidis dan 1 sampel Staphylococcus aureus, Pseudomonas aeruginosa, Proteus vulgaris dan Proteus mirabilis. Kemudian dilakukan identifikasi bakteri dan uji resisitensi antibiotik terhadap 5 jenis antibiotik dengan menggunakan metode difusi. Jenis bakteri yang banyak ditemukan dalam pus ulkus diabetikum berturur-turut adalah Klebsiella pneumonia (40\%), Staphylococcus epidermidis (60\%). Proteus vulgaris (10\%), Proteus mirabilis (10\%), Pseudomonas aeruginosa (10\%) dan Staphylococcus aureus (10\%). Ciprofloksasin dan cefotaxime menduduki peringkat tertinggi tingkat resistensi dengan jumlah resistensi bakteri terbanyak (40\%), disusul Meropenem dan Gentamisin (30\%), sedangkan Vankomisin efektif digunakan pada bakteri Staphylococcus aureus dan Staphylococcus epidermidis dengan tingkat resistensi (0\%).
\end{abstract}

Kata kunci : Ulkus diabetikum, Identifikasi Bakteri, Resistensi Antibiotik

\begin{abstract}
Diabetic ulcers is one of diabetic mellitus's chronic complication such as open wound on the skin and can be accompanied by necrotic tissues. High blood glucose levels become a strategic area to the development of bacteria. This study aims to determine the bacterial agent that cause of diabetic ulcer and its resistance to antibiotics. The design of this study was true experiment with diabetic ulcers patients as the subject in the ward interne at RSUP Dr. M. Djamil Padang on period February - April 2019. In this study 10 samples of diabetic ulcer patients were obtained, then bacterial identification and antibiotic resistance test was done against 5 types of antibiotics ciprofloxacin, cefotaxime, meropenem, gentamicin and vankomicin. Consecutively most of bacteria found were Klebsiella pneumonia (40\%), Staphylococcus epidermidis (60\%). Proteus vulgaris $(10 \%)$, Proteus mirabilis $(10 \%)$, Pseudomonas aeruginosa $(10 \%)$ and Staphylococcus aureus (10\%). Ciprofloxacin and Cefotaxime had the highest level of bacterial resistance (40\%), while Vancomicin is effective to used in Staphylococcus aureus and Staphylococcus epidermidis.
\end{abstract}

Keywords: Diabetic Ulcer, Bacterial Identification, Antibiotic Resistance

\section{PENDAHULUAN}

Diabetes melitus merupakan penyakit yang ditandai dengan peningkatan kadar glukosa darah baik disebabkan oleh kerusakan pankreas maupun resistensi insulin ataupun keduanya yang ditandai oleh hiperglikemia yang berhubungan dengan kelainan karbohidrat, lemak, metabolisme protein dan komplikasi kronis termasuk mikrovaskular dan gangguan neuropatik (Yunir, 2006). Gangguan pada neuropati meningkatkan morbiditas, terutama melalui perannya dalam patogenesis ulkus diabetik (McPhee $d k k, 2010$ ).

Menurut hasil Riset Kesehatan Dasar berdasarkan prevalensinya diabetes berada di urutan ke-4 penyakit kronis di Indonesia dan terjadi peningkatan penderita diabetes melitus di Indonesia dari 1,1\% ditahun 2007 menjadi 2,4\% di tahun 2013 (Riset Kesehatan Dasar (Riskesdas), 2013) Selain itu, International Diabetes Federation (IDF) memprediksi adanya kenaikan jumlah penyandang diabetes di Indonesia dari 9,1 juta pada tahun 2014 menjadi 14,1 juta pada tahun 2035 (Dirk $d k k, 2014$ ).

Merujuk kepada prevalensi nasional, Sumatera Barat memiliki prevalensi total diabetes sebanyak $1,3 \%$, dimana Sumatera Barat berada diurutan 14 dari 33 provinsi yang ada di Indonesia. Berdasarkan umur, penderita banyak dalam rentang usia 56-64 tahun dengan prevalensi sebesar 4,8\% (Kemenkes RI, 2013). Berdasarkan data survey pendahuluan, didapatkan hasil bahwa pasien diabetes melitus yang 
dirawat di RSUP Dr. M. Djamil Padang sebanyak 934 pasien pada tahun 2017.

Salah satu komplikasi diabetes melitus adalah ulkus, dimana terjadinya infeksi superfisial pada kulit penderita. Masuknya bakteri menjadi awal terjadinya ulkus dan kadar glukosa yang tinggi menjadi tempat strategis perkembangan bakteri. Bakteri yang terdapat dalam ulkus diabetikum merupakan gabungan antara bakteri aerob dan anaerob (Hastuti, 2008). Berdasarkan penelitian Patil $d k k$, jenis bakteri yang paling banyak ditemukan dalam ulkus diabetikum adalah bakteri gram negatif sebanyak 79,6\% dan bakteri gram positif sebanyak 20,4\%. Bakteri gram negatif yang ditemukan adalah Pseudomonas aeruginosa (19,75\%), Klebsiella pnemoniae (17,9\%), Acinetobacter sp (16,7\%), E.coli (14,8\%), Proteus sp (4,9\%), Citrobacter sp (4,3\%) dan Enterotobacter sp (1,2\%). Pada bakteri gram positif ditemukan Staphylococcus aureus (13,6\%), Coagulase negatif Staphylococcus (CONS) $(3,7 \%)$ dan Enterococcus sp $(3,1 \%)$ (Patil $d k k$, 2018).

Pengobatan ulkus dengan infeksi bakteri kultur positif dianjurkan dengan pemberian antibiotik. Antibiotik memiliki kemampuan menghambat pertumbuhan bakteri (Lipsky $d k k$, 2012). Menurut penelitian yang dilakukan Patil $d k k$, antibiotik yang paling efektif untuk digunakan untuk bakteri gram positif adalah imipenem dengan persentsase 74,3\% dan untuk baketri gram negatif adalah vancomycin dan linezolid dengan persentase 100\%. Sementara, tingkat resistensi tertinggi ditemukan pada antibiotik eritromisin, tetrasiklin dan ciprofloxacin (Patil $d k k$, 2018).

Berdasarkan uraian di atas, maka peneliti ingin melakukan penelitian untuk mengidentifikasi dan mengetahui pola resistensi antibiotik pada pasien ulkus diabetikum di bangsal interne RSUP Dr. M. Djamil, Padang. Bakteri diidentifikasi dari ulkus pasien, dimana dengan diketahui jenis bakterinya dan pola resistensinya maka akan lebih memudahkan dalam pemilihan antibiotik.

\section{METODE PENELITIAN}

\section{Tempat dan Waktu Penelitian}

Penelitian ini telah dilakukan pada bulan Februari - April 2019 di RSUP DR. M. Djamil Padang dan Laboratorium Mikrobiologi Fakultas Kedokteran Universitas Andalas.

\section{Jenis dan Desain penelitian}

Padang. Kriteria inklusi dalam penelitian adalah pasien dengan diagnosa utama penyakit ulkus diabetikum dengan atau tanpa penyakit penyerta.
Jenis penelitian ini adalah penilitian deskriptif eksploratif dengan desain secara prospektif. Data penelitian diambil dari pasien ulkus diabetikum di bangsal Interne RSUP Dr. M. Djamil Padang dan Laboratorium Mikrobiologi Fakultas Kedokteran Universitas Andalas.

\section{Populasi}

Populasi dalam penelitian ini adalah pasien dengan diagnosa penyakit ulkus diabetikum yang di rawat inap di bangsal interne RSUP DR. M. Djamil Padang.

\section{Sampel}

Sampel penelitian ini adalah pasien ulkus diabetikum yang di rawat inap di bangsal interne RSUP DR. M. Djamil Padang pada bulan Februari April 2019 yang memenuhi kriteria inklusi.

\section{Alat}

Alat yang digunakan dalam penelitian ini adalah kapas lidi steril, cawan petri $\left(\right.$ Petrio $\left.^{\circledR}\right)$, wadah steril, tabung reaksi, rak tabung reaksi, beaker glass, gelas ukur, Erlenmeyer $\left(\right.$ Pyrex $\left.^{\circledR}\right)$, bunsen, mikroskop, kaca objek, penggaris, ose, autoklaf (All American $^{\circledR}$ ), inkubator $\left(\right.$ Gallenkamp $\left.{ }^{\circledR}\right)$, pinset, lemari pendingin, pipet mikro (Tranferpette ${ }^{\mathbb{R}}$ ), kapas steril dan label.

\section{Bahan}

Bahan yang digunakan dalam penelitian ini adalah pus ulkus pasien penderita diabetes melitus yang dirawat inap pada bangsal interne RSUP Dr. M. Djamil Padang, Media penyubur: Media FTM, Untuk penanaman sampel: Media Blood Agar $\left(\mathrm{BBL}^{\circledR}\right)$ dan Media Mac Conkey $\left(\mathrm{BBL}^{\circledR}\right)$, media untuk uji biokimia: media Triple Sugar Iron Agar (TSIA) $\left(\mathrm{BBL}^{\circledR}\right)$, media SIM $\left(\mathrm{BBL}^{\circledR}\right)$ dan media Simmon Citrat Agar $\left(\mathrm{BBL}^{\circledR}\right)$, untuk uji resistensi antibiotik: disk antibiotik, Mc Farland 0,5, Mueller Hinton Agar, $\mathrm{NaCl}$ 0,9\%, untuk uji katalase: Reagen $\mathrm{H}_{2} \mathrm{O}_{2} 3 \%$ dan bakteri untuk uji koagulase digunakan plasma citrat dan bakteri, alkohol 96\%,alkohol $70 \%$, larutan Kristal violet, larutan Lugol, larutan safranin.

\section{Pengambilan Sampel}

Sampel yang diambil berupa pus ulkus pasien penderita diabetes mellitus yang dirawat inap di bangsal interne RSUP Dr. M. Djamil

Bersihkan ulkus dengan kain kasa steril yang telah dibasahi $\mathrm{NaCl}$ fisiologis secara hati-hati, kemudian ulang perlakuan tersebut sebanyak 2 kali. Ulkus dipencet dan usapkan kapas lidi steril ke 
bagian ulkus tanpa mengenai tepi ulkus. Masukkan hasil swab ulkus ke dalam wadah steril. Tutup tabung dengan erat dan diberi nama menggunakan label (Nur $d k k$, 2012). Sampel swab ulkus kemudian dibawa ke Laboratorium Mikrobiologi RSUP Dr. M. Djamil Padang.

\section{Penanaman dan Isolasi Bakteri}

Sampel di swab lalu diinokulasi pada media Mac Conkey dan Blood Agar, lalu diinkubasi dengan keadaan terbalik pada suhu $37^{\circ} \mathrm{C}$ selama 24 jam. Setelah diinkubasi dilakukan identifikasi koloni yang tumbuh dengan pewarnaan Gram, reaksi biokimia untuk Gram negatif, dan untuk Gram positif digunakan tes katalase yang membedakan Staphylococcus dengan Streptococcus, tes koagulase untuk membedakan Staphylococcus aureus dengan Staphylococcus epidermidis (Suhartati $d k k$, 2014).

\section{Identifikasi Bakteri}

Identifikasi bakteri dilakukan dengan pewarnaan Gram dan uji biokimia. Untuk bakteri Gram positif akan dilakukan uji bikomia antara lain : Tes Katalase, Tes Novobiosin dan Tes Koagulase. Sedangkan untuk bakteri Gram negatif akan dilakukan uji biokomia antara lain : Uji TSIA, Uji Simmon Citrate dan Uji SIM (Clinical and Laboratory Standards Institute (CLSI), 2014).

\section{Penentuan Resistensi Antibiotika}

a. Penyiapan Disk Antibiotik

Disk antibiotik yang digunakan dengan konsentrasi yang telah ditetapkan.

b. Pembuatan Suspensi Bakteri Uji

Sebanyak 1-2 ose koloni bakteri uji disuspensikan dalam 1-2 $\mathrm{mL} \mathrm{NaCl}$ fisiologis dalam tabung reaksi steril dan dihomogenkan dengan ose, kemudian dibandingkan kekeruhan dari suspensi dengan standar McFarland 0,5. Perlakuan yang sama dilakukan pada setiap jenis bakteri uji

c. Penentuan Resistensi Antibiotika dengan Metoda Difusi Agar

Suspensi bakteri diambil dengan kapas lidi steril dan ditanam pada media Mueller Hinton Agar dengan cara mengoleskan secara merata pada permukaan media, kemudian disk antibiotik diletakkan dengan hati-hati diatas permukaan media dan ditekan perlahan dengan pinset steril supaya benar-benar kontak dengan bakteri yang terdapat pada media. Jarak disk dengan tepi cawan petri 15 $\mathrm{mm}$ dan jarak antar disk $24 \mathrm{~mm}$. Biakan diinkubasi pada suhu $37^{\circ} \mathrm{C}$ selama 24 jam.

jaringan setempat. Pada penelitian ini menggunakan jenis penelitian deskripsi eksploratif dengan desain
Karakterisasi dengan mengukur dan membandingkan diameter daerah hambatan terhadap tabel standar. Sensitif (S) dan resisten (R) terhadap antibiotik disimpulkan berdasarkan diameter daerah bening hambatan disekiar disk antibiotik (Bonang dkk, 2002).

\section{d. Perhitungan Persentase Resistensi (Harley,} 2002).

Persentase resistensi antibiotik dihitung untuk setiap jenis antibiotik denganmenggunakan persamaan :

$\%$ Resistensi $=\frac{\text { Jumlah kultur yang resisten }}{\text { Jumlah kultur yang diuji }} \times 100 \%$

e. Perhitungan Nilai Multiple Antibacterial Resisten (MAR) (Harley, 2002).

Perhitungan nilai MAR dengan menggunakan persamaan Krumperman :

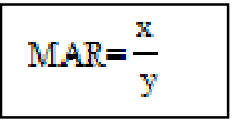

Keterangan :

$\begin{aligned} \text { MAR = } & \text { Multipel Antibacterial Resisten } \\ \mathrm{X}= & \text { Jumlah bagian yang resisten } \\ & \text { terhadap antibiotik dari satu kultur } \\ & \text { yang digunakan } \\ \mathrm{Y}= & \text { Jumlah antibiotik yang digunakan }\end{aligned}$

\section{Analisis Data}

Dari data yang diperoleh, dihitung angka resistensi masing-masing bakteri penyebab ulkus diabetikum yang ditemukan terhadap lima jenis antibiotik uji dan angka resistensi. Persentase resistensi yang didapatkan dari hasil penelitian disajikan dalam bentuk diagram batang dan dianalisis secara deskriptif.

\section{HASIL DAN PEMBAHASAN}

Ulkus diabetik adalah salah satu komplikasi kronis diabetes melitus berupa luka terbuka pada permukaan kulit yang dapat disertai adanya kematian jaringan setempat. Pada penelitian ini menggunakan jenis penelitian deskripsi eksploratif dengan desain Ulkus diabetik adalah salah satu komplikasi kronis diabetes melitus berupa luka terbuka pada permukaan kulit yang dapat disertai adanya kematian

secara prospektif. Pasien yang memenuhi kriteria inklusi sebanyak 10 orang dan pasien yang tidak 
memenuhi kriteria eksklusi sebanyak 2 orang. Sepuluh sampel yang diperoleh, selanjutnya dilakukan isolasi dan uji biokimia untuk mendapatkan bakteri penyebab ulkus diabetikum. Hasil uji tersebut disajikan dalam bentuk tabel berikut :

Berdasarkan tabel dibawah ini dari 10 subjek penelitian didapatkan hasil bakteri terbanyak adalah Klebsiella pneumonia dengan persentasi $40 \%$ diikuti Staphylococcus epidermidis dengan persentasi 20\%, Proteus vulgaris, Proteus mirabilis, Pseudomonas aeriginosa dan Staphlococcus aureus dengan persentasi $10 \%$. Tingginya tingkat resistensi Klebsiella pneumonia terhadap beberapa antibiotik dikarenakan Klebsiella sp. merupakan patogen utama dirumah sakit (Ferreira $d k k$, 2011).
Hasil ini tidak jauh berbeda dengan penelitian yang dilakukan oleh Gaol (2014) didapatkan hasil bahwa bakteri penyebab ulkus diabetikum terbanyak adalah Klebsiella sp dengan persentase 34\%. Tetapi pada penelitian yang dilakukan oleh Nur (2016) bahwa penyebab bakteri ulkus diabetikum terbanyak pada bakteri gram negatif adalah Klebsiella $s p$ dengan persentase $75,4 \%$. Penyebab perbedaan hasil dengan peneliti sebelumnya antara lain dikarenakan adanya perbedaan demografi, faktor resiko yang mendasari dan lamanya waktu rawat inap pasien (Aly $d k k$, 2016). Meskipun terdapat perbedaan persentase Klebsiella sp. pada penelitian diatas, namun Klebsiella sp. menempati urutan pertama yang menjadi penyebab ulkus diabetikum.

Tabel 1. Hasil Uji Biokimia

\begin{tabular}{|c|c|c|c|c|c|c|c|c|c|c|}
\hline \multirow{2}{*}{$\begin{array}{l}\text { No. } \\
\text { sampel }\end{array}$} & \multirow{2}{*}{$\begin{array}{l}\text { Bakteri Tumbuh } \\
\text { Pada Media }\end{array}$} & \multirow{2}{*}{$\begin{array}{l}\text { Pewarnaan } \\
\text { Gram }\end{array}$} & \multicolumn{7}{|c|}{ Uji Biokimia } & \multirow[b]{2}{*}{ Kesimpulan } \\
\hline & & & TSIA & Indol & Motil & $\mathrm{H}_{2} \mathrm{~S}$ & SC & Koagulase & Katalase & \\
\hline 1 & Blood Agar & $\operatorname{Gram}(+)$ & - & - & - & - & - & + & + & S.aures \\
\hline 2 & Blood Agar & $\operatorname{Gram}(+)$ & - & - & - & - & - & - & + & S.epidermidis \\
\hline 3 & Mc Conkey Agar & Gram (-) & $\mathrm{K} / \mathrm{A}$ & - & - & - & + & - & - & K.pneumonia \\
\hline 4 & Mc Conkey Agar & Gram (-) & $\mathrm{K} / \mathrm{A}$ & - & + & + & $+/-$ & - & - & Pro.mirabilis \\
\hline 6 & Mc Conkey Agar & Gram (-) & $\mathrm{K} / \mathrm{A}$ & - & - & - & + & - & - & K.pneumonia \\
\hline 7 & Mc Conkey Agar & Gram (-) & $\mathrm{A} / \mathrm{A}$ & + & + & + & + & - & - & Pro.vulgaris \\
\hline 8 & Mc Conkey Agar & Gram (-) & $\mathrm{K} / \mathrm{A}$ & - & - & - & + & - & - & K.pneumonia \\
\hline 9 & Mc Conkey Agar & Gram (-) & $\mathrm{K} / \mathrm{A}$ & - & - & - & + & - & - & K.pneumonia \\
\hline 10 & Blood Agar & $\operatorname{Gram}(+)$ & - & - & - & - & - & - & + & S.epidermidis \\
\hline 12 & Mc Conkey Agar & Gram (-) & $\mathrm{K} / \mathrm{K}$ & - & + & - & + & - & - & P.aeruginosa \\
\hline
\end{tabular}

Pada penelitian ini dilakukan juga uji resistensi terhadap beberapa antibiotik yaitu Ciprofloksasin, Cefotaxime, Meropenem, Gentamisin, dan Vankomisin. Ciprofloksasin, Cefotaxime, Meropenem, Gentamisin adalah antibiotik yang sering digunakan sebagai terapi pengobatan ulkus diabetikum di RSUP Dr. M. Djamil Padang dan antibiotik Vankomisin adalah antibiotik yang saat ini sering digunakan pada ulkus diabetikum yang disebabkan oleh bakteri gram positif karena efektif untuk membunuh bakteri tersebut.

Tabel 2. Angka Resistensi Bakteri terhadap Antibiotik Ciprofloksasin

\begin{tabular}{|l|l|c|c|c|c|c|c|c|}
\hline \multirow{2}{*}{ No } & \multicolumn{2}{|c|}{ Bakteri yang ditemukan pada Sampel } & \multicolumn{5}{|c|}{ Resistensi terhadap Ciprofloksasin } \\
\cline { 2 - 9 } & \multicolumn{1}{|c|}{ Jenis } & 1 & 0 & 0,00 & 0 & 0,00 & 1 & 100 \\
\hline 1. & Proteus Vulgaris & 1 & 0 & 0,00 & 1 & 100 & 0 & 0,00 \\
\hline 2. & Proteus Mirabilis & 4 & 2 & 50 & 0 & 0,00 & 2 & 50 \\
\hline 3. & Klebsiella pneumonia & 1 & 0 & 0,00 & 0 & 0,00 & 1 & 100 \\
\hline 4. & Pseudomonas aeruginosa & 1 & 0 & 0,00 & 0 & 0,00 & 1 & 100 \\
\hline 5. & Staphylococcus aureus & 2 & 2 & 100 & 0 & 0,00 & 0 & 0,00 \\
\hline 6. & Staphylococcus epidermidis & $\mathbf{1 0}$ & $\mathbf{4}$ & $\mathbf{4 0}$ & $\mathbf{1}$ & $\mathbf{1 0}$ & $\mathbf{5}$ & $\mathbf{5 0}$ \\
\hline
\end{tabular}

Berdasarkan tabel diatas diperoleh hasil bahwa antibiotik ciprofloksasin telah resisten terhadap bakteri $K$. pneumonia dan $S$. epidermidis dengan persentase masing-masing 50\% dan 100\%. Hasil ini 
tidak jauh berbeda dengan hasil penelitian yang dilakukan Patil (2018) bahwa cefotaxime memiliki tingkat resistensi yang tinggi terhadap Klebsiella pneumonia yaitu sebesar $51,7 \%$.

Tingginya resistensi ciprofloksasin terhadap $S$. epidermidis dapat timbul selama terapi melalui mutasi gen kromosom bakteri yang mengkode DNAgirase atau topoisomerase IV atau melalui transport aktif obat keluar dari bakteri, sehingga tidak teridentifikasinya aktivas bakteri yang memodifikasi atau mengaktivasi kuinolon (Gilman $d k k$, 2012) sedangkan pada $K$. pneumonia terhadap ciprofloksasin dikarenakan mekanisme perubahan pada permukaan sel bakteri yang mempersulit penetrasi obat ke dalam sel dan dapat dimungkinkan karena peningkatan mekanisme pemompaan obat keluar sel (Setiawan $d k k, 2010)$.

Tabel 3. Angka Resistensi Bakteri terhadap Antibiotik Cefotaksim

\begin{tabular}{|l|l|c|c|c|c|c|c|c|}
\hline \multirow{2}{*}{ No } & \multicolumn{1}{|c|}{ Bakteri yang ditemukan pada Sampel } & \multicolumn{5}{c|}{ Resistensi terhadap Cefotaxim } \\
\cline { 2 - 8 } & \multicolumn{1}{|c|}{ Jenis } & Jumlah & R & $\%$ & I & $\%$ & S & $\%$ \\
\hline 1. & Proteus Vulgaris & 1 & 0 & 0,00 & 0 & 0,00 & 1 & 100 \\
\hline 2. & Proteus Mirabilis & 4 & 3 & 75 & 1 & 25 & 0 & 0,00 \\
\hline 3. & Klebsiella pneumonia & 1 & 0 & 0,00 & 0 & 0,00 & 1 & 100 \\
\hline 4. & Pseudomonas aeruginosa & 1 & 0 & 0,00 & 0 & 0,00 & 1 & 100 \\
\hline 5. & Staphylococcus aureus & 2 & 1 & 50 & 1 & 0,00 & 0 & 0,00 \\
\hline 6. & Staphylococcus epidermidis & $\mathbf{1 0}$ & $\mathbf{4}$ & $\mathbf{4 0}$ & $\mathbf{2}$ & $\mathbf{2 0}$ & $\mathbf{4}$ & $\mathbf{4 0}$ \\
\hline
\end{tabular}

Berdasarkan tabel diatas diperoleh hasil bahwa antibiotik Cefotaxime telah resisten terhadap bakteri $K$. pneumonia dan $S$. epidermidis dengan persentase masing-masing $75 \%$ dan $50 \%$. Hasil ini tidak jauh berbeda dengan hasil penelitian yang dilakukan Patil (2018) bahwa cefotaxime memiliki tingkat resistensi yang tinggi terhadap Klebsiella pneumonia yaitu sebesar 75,9 \% dan hasil penelitian yang dilakukan Setianingsih (2016) bahwa cefotaxime memiliki tingkat resistensi yang tinggi terhadap Staphylococcus epidermidis yaitu sebesar $50 \%$.
Resistensi Cefotaxime terhadap bakteri Klebsiella sp. dapat dikarenakan cefotaxime merupakan antibiotik golongan $\beta$-laktam, dimana enzim yang dihasilkan tersebut dapat melawan antibiotik golongan $\beta$-lactam (Rizal, 2010). Sedangkan, pada bakteri $S$. epidermidis dikarenakan ketidakmampuan antibiotik untuk mencapai tempat kerjanya atau perubahan dalam PBP yang merupakan targetnya.

Tabel 4. Angka Resistensi Bakteri terhadap Antibiotik Meropenem

\begin{tabular}{|l|l|c|c|c|c|c|c|c|}
\hline \multirow{2}{*}{ No } & Bakteri yang ditemukan pada Sampel & \multicolumn{5}{|c|}{ Resistensi terhadap Meropenem } \\
\cline { 2 - 8 } & Jenis & Jumlah & R & $\%$ & I & $\%$ & S & $\%$ \\
\hline 1. & Proteus Vulgaris & 1 & 0 & 0,00 & 0 & 0,00 & 1 & 100 \\
\hline 2. & Proteus Mirabilis & 4 & 1 & 25 & 0 & 0,00 & 3 & 75 \\
\hline 3. & Klebsiella pneumonia & 1 & 0 & 0,00 & 0 & 0,00 & 1 & 100 \\
\hline 4. & Pseudomonas aeruginosa & 1 & 0 & 0,00 & 0 & 0,00 & 1 & 100 \\
\hline 5. & Staphylococcus aureus & 2 & 2 & 100 & 0 & 0,00 & 0 & 0,00 \\
\hline 6. & Staphylococcus epidermidis & $\mathbf{1 0}$ & $\mathbf{3}$ & $\mathbf{3 0}$ & $\mathbf{0}$ & $\mathbf{0 , 0 0}$ & $\mathbf{7}$ & $\mathbf{7 0}$ \\
\hline
\end{tabular}

Berdasarkan tabel diatas didapatkan hasil bahwa antibiotik Meropenem telah resisten terhadap bakteri $K$. pneumonia dan $S$. epidermidis dengan persentase masing-masing $25 \%$ dan $100 \%$. Hasil ini tidak jauh berbeda dengan penelitian yang dilakukan Setianingsih (2016) bahwa meropenem memiliki tingkat resistensi yang tinggi terhadap Staphylococcus epidermidis yaitu sebesar $50 \%$.
Resistensi meropenem terhadap K. pneumonia dapat terjadi ketika bakteri bakteri mengubah struktur protein binding proteins dan menghasilkan enzim metallo-beta-lactamases yang dapat secara cepat mendegradasi meropenem atau ketika permeabilitas membran bakteri berubah sebagai akibat hilangnya spesifitas outer membrane porins (Ludden $d k k, 2015$ ). Protein membran luar Klebsiella 
sp. Terdiri dari 3 jenis porin yaitu OmpK35, OmpK36 dan OmpK37. Porin OmpK35 dan OmpK36 berperan penting pada penetrasi antibiotik ke dalam sel, sehingga hilangnya porin OmpK35 dan OmpK36 dapat menyebabkan resistensi bakteri terhadap carbapenem (Kontopoulou $d k k, 2010$ ).
Sedangkan pada bakteri $S$. epidermidis meropenem memiliki aktivitas yang rendah terhadap bakteri gram positif sehingga mudah untuk terjadinya resistensi terhadap bakteri gram positif karena meropenem dengan aktivitas yang kecil tidak mampu melewati dinding sel dari bakteri gram positif.

Tabel 5. Angka Resistensi Bakteri terhadap Antibiotik Gentamisin

\begin{tabular}{|l|l|c|c|c|c|c|c|c|}
\hline \multirow{2}{*}{ No } & \multicolumn{1}{|c|}{ Bakteri yang ditemukan pada Sampel } & \multicolumn{5}{|c|}{ Resistensi terhadap Gentamisin } \\
\cline { 2 - 8 } & \multicolumn{1}{|c|}{ Jenis } & Jumlah & R & $\%$ & I & $\%$ & S & $\%$ \\
\hline 1. & Proteus Vulgaris & 1 & 0 & 0,00 & 0 & 0,00 & 1 & 100 \\
\hline 2. & Proteus Mirabilis & 1 & 0 & 0,00 & 0 & 0,00 & 1 & 100 \\
\hline 3. & Klebsiella pneumonia & 4 & 2 & 50 & 0 & 0,00 & 2 & 50 \\
\hline 4. & Pseudomonas aeruginosa & 1 & 0 & 0,00 & 0 & 0,00 & 1 & 100 \\
\hline 5. & Staphylococcus aureus & 1 & 0 & 0,00 & 0 & 0,00 & 1 & 100 \\
\hline 6. & Staphylococcus epidermidis & 2 & 1 & 50 & 0 & 0,00 & 1 & 50 \\
\hline & Total & $\mathbf{1 0}$ & $\mathbf{3}$ & $\mathbf{3 0}$ & $\mathbf{0}$ & $\mathbf{0 , 0 0}$ & $\mathbf{7}$ & $\mathbf{7 0}$ \\
\hline
\end{tabular}

Berdasarkan tabel diatas diperoleh hasil bahwa antibiotik gentamisin telah resisten terhadap bakteri $K$. pneumonia dan $S$. epidermidis dengan persentase masing-masing 50\% dan 50\%. Hasil ini sesuai dengan hasil penelitian yang dilakukan Patil (2018) bahwa gentamisin memiliki tingkat resistensi terhadap klebsiella pneumonia yaitu sebesar 48,3\%.

Tingginya tingkat resistensi $K$. pneumonia terhadap gentamisin dapat disebabkan kegagalan penetrasi kedalam bakteri, rendahnya afinitas pada ribosom atau inaktivasi obat oleh enzim bakteri (Setiawan $d k k, 2010$ ). Sedangkan pada bakteri $S$. epidermidis disebabkan oleh tidak permeabelnya membran bakteri terhadap obat sehingga terjadi perubahan pada membran luar yang menganggu transport aktif ke dalam sel.

Tabel 6. Angka Resistensi Bakteri terhadap Antibiotik Vankomisin

\begin{tabular}{|l|l|c|c|c|c|c|c|c|}
\hline \multirow{2}{*}{ No } & \multicolumn{2}{|c|}{ Bakteri yang ditemukan pada Sampel } & \multicolumn{5}{c|}{ Resistensi terhadap Vankomisin } \\
\cline { 2 - 8 } & \multicolumn{1}{|c|}{ Jenis } & Jumlah & $\mathrm{R}$ & $\%$ & $\mathrm{I}$ & $\%$ & $\mathrm{~S}$ & $\%$ \\
\hline 1. & Proteus Vulgaris & 0 & 0 & 0,00 & 0 & 0,00 & 0 & 0,00 \\
\hline 2. & Proteus Mirabilis & 0 & 0 & 0,00 & 0 & 0,00 & 0 & 0,00 \\
\hline 3. & Klebsiella pneumonia & 0 & 0 & 0,00 & 0 & 0,00 & 0 & 0,00 \\
\hline 4. & Pseudomonas aeruginosa & 1 & 0 & 0,00 & 1 & 100 & 0 & 0,00 \\
\hline 5. & Staphylococcus aureus & 2 & 0 & 0,00 & 0 & 0,00 & 2 & 100 \\
\hline 6. & Staphylococcus epidermidis & $\mathbf{3}$ & $\mathbf{0}$ & $\mathbf{0 , 0 0}$ & $\mathbf{1}$ & $\mathbf{3 3 , 3 3}$ & $\mathbf{2}$ & $\mathbf{6 6 , 6 7}$ \\
\hline
\end{tabular}

Berdasarkan tabel diatas diperoleh hasil bahwa antibiotik vankomisin asih sensitif terhadap bakteri Staphylococcus aureus dan Staphylococcus epidermidis karena antibiotik ini merupakan antibiotik yang paling aktif untuk membunuh bakteri gram positif. Hasil ini sesuai dengan penelitian yang dilakukan Patil (2018) dan Setianingsih (2016) bahwa antibiotik memliki tingkat sensitifitas yang besar terhadap $S$. aureus dan $S$. epidermidis yaitu dengan persentase $100 \%$. Tetapi di beberapa rumah sakit di Indonesia masih jarang yang menggunakan antibiotik ini sebagai terapi pengobatan karena sebelum pemberian antibiotik ini harus dilakukan tes uji laboratorium terhadap pus pasien ulkus diabetikum.

Mekanisme timbulnya resistensi bakteri terhadap antibiotik berbeda untuk masing-masing bakteri, yaitu dengan cara bakteri menghasilkan enzim dan merusak obat yang aktif, bakteri merubah permeabilitasnya terhadap obat, bakteri mengubah struktur target terhadap obat, bakteri mengembangkan jalur metabolisme baru yang menghindari jalur yang biasa dihambat oleh obat dan bakteri mengembangkan enzim baru yang masih dapat melakukan fungsi metaboliknya tapi sedikit dipengaruhi obat (Jawetz $d k k, 2010)$. 
Jurnal Penelitian Farmasi Indonesia 8(2), Desember 2019

ISSN 2302-187X e-ISSN 2656-3614

\section{Hasil Uji Resistensi}

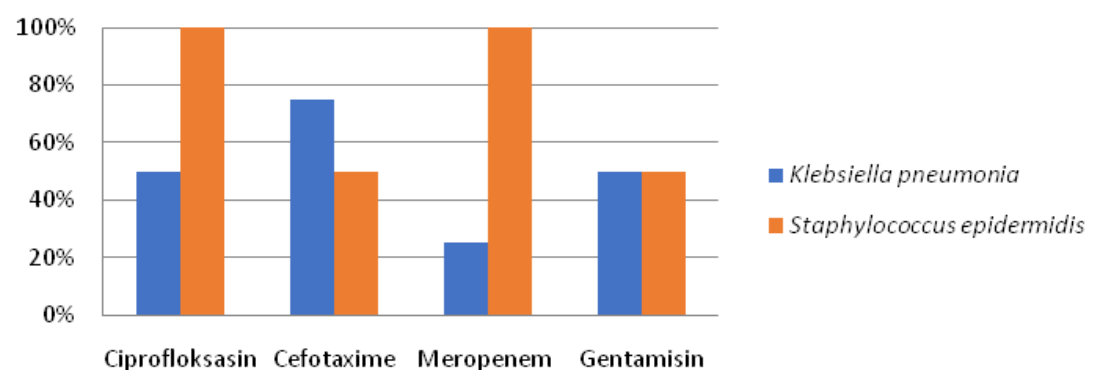

\section{Hasil uji Sensitivitas}

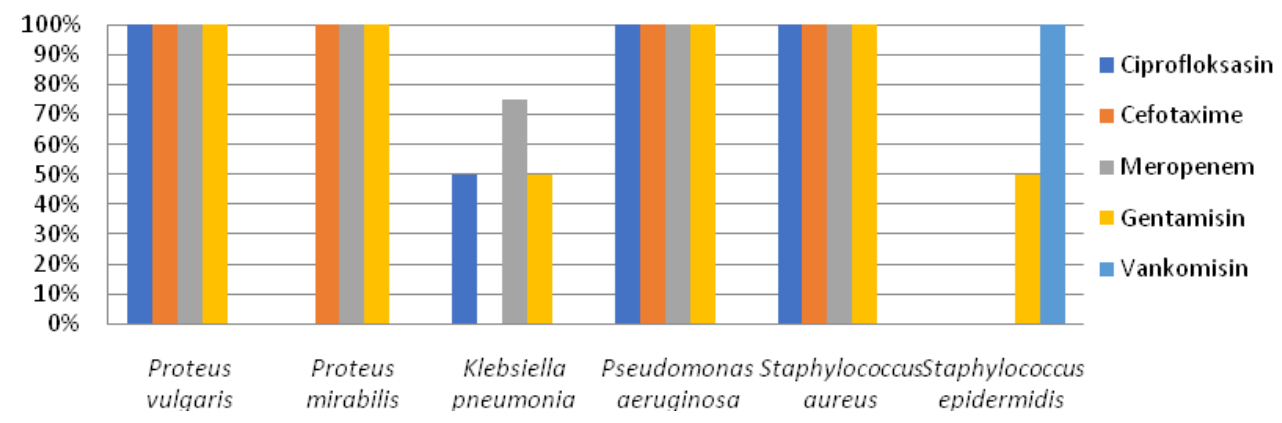

Gambar 1 Hasil Uji resistensi dan Sensitivitas Bakteri Terhadap Antibiotik

Dari hasil uji resistensi yang dilakukan, persentasi resisten antibiotik tertinggi terdapat pada antibiotik ciprofloksasin dan cefotaxime dengan persentase $40 \%$ diikuti oleh meropenem dan gentamisin dengan persentase $30 \%$ dan vankomisin tidak ditemukannya resisten terhadap bakteri.

Berdasarkan Nilai Multiple Antibiotic (MAR) diperoleh nilai untuk $S$. Epidermidis adalah 0,6, untuk $K$. Pneumoniae adalah 0,5. P. Aeruginosa, $P$. Mirabilis, $P$. Vulgaris dan S. aureus adalah 0,00. Pada perhitungan nilai MAR dikatakan resistensi apabila nilai yang diperoleh $>0,2$ sehingga bakteri $S$. Epidermidis dan $K$. Pneumoniae sudah resisten terhadap beberapa antibiotik yang digunakan. Tingginya nilai MAR tersebut menunjukkan bahwa bakteri mempunyai tingkat resistensi yang tinggi terhadap antibiotik tersebut.

Tingginya tingkat resistensi dan lamanya perawatan terhadap pasien dikarenakan tingginya kadar glukosa di dalam darah pada pasien ulkus diabetikum. Sebagaimana yang diketahui glukosa merupakan salah satu nutrisi bakteri untuk dapat tumbuh dan berkembang, sehingga hal tersebut menyebakan bakteri sulit untuk mati walaupun diberikan antibiotik (Nur $d k k, 2016)$.
Beberapa bakteri resisiten terhadap antibiotika tertentu. Bakteri dikatakan resisten apabila pertumbuhannya tidak dihambat oleh antibiotika pada kadar maksimum yang dapat ditolerir oleh penjamu. Efek dari antibiotika terhadap tanda-tanda infeksi pasien masih terdapat variasi antara pasien satu dengan pasien lainnya dikarenakan berbagai faktor seperti penggunaan antibotik, faktor adanya penyakit lain, faktor kebersihan ulkus kaki sehingga memudahkan untuk masuknya bakteri dari luar, faktor tingkat keparahan infeksi saat datang dan faktor kondisi imunitas dan gizi pasien, sehingga perlu diberikan dasar terapi empiris dan untuk mengurangi resiko komplikasi.

Berdasarkan hasil penelitian ini diharapkan menjadi salah satu gambaran terhadap jenis bakteri penyebab ulkus diabetikum dan pola resisten antibiotik seperti ciprofloksasin, cefotaxime, meropenem, gentamisin dan vankomisin, sehingga menjadi salah satu cara untuk mencegah dan mengurani tingkat resistensi antibiotik sebagai terapinya.

\section{DAFTAR PUSTAKA}


Jurnal Penelitian Farmasi Indonesia 8(2), Desember 2019

Catheter-Associated Urinary Tract Infection In The Intensive Care Unit Of Assiut University Hospital. Al Azhar Assiut Medical Journal. 14(2):52-58.

Bonang., Gerard., Koeswardono., dan Enggar, S. 2002. Mikrobiologi Kedokteran untuk Laboratorium dan Klinik. Jakarta Gramedia.

Clinical and Laboratory Standards Institute (CLSI). 2014. Performance Standards for Antimicrobial Susceptibility Testing : Twenty Fourth International Supplement, Clinical and Laboratory Standards Insitute, Wayne.

Dirk, S. Y. P. R., dan Waworuntu, L. V. 2014. Sensitivitas Antibiotik terhadap Bakteri yang Diisolasi dari Ulkus Diabetika di RSUD Abepura, Jurnal Biologi Papua : Kota Jayapura, 6(2): 53-59.

Ferreira, C. M., Ferreira, W. A., Almeida, N. C. O. S., Naveca, F. G., Barbosa, M. G. V. 2011. Extended-Spectrum BetaLactamase-Producing Bacteria Isolated From Hematologic Patients In Manaus, State Of Amazonas, Brazil. Brazilian Journal Of Microbiology. 42(3):1076-1084.

Gaol, Y. E. L., Erly., dan Elmatris, S.Y. 2014. Pola Resistensi Bakteri Aerob Pada Ulkus Diabetik Terhadap Beberapa Antibiotika di Laboratorium Mikrobiologi RSUP Dr. M. Djamil Padang Tahun 2011-2013, Jurnal Kesehatan Andalas, 6(1).

Gilman, Goodman A. 2012, Goodman \& Gilman. Dasar Farmakologi Terapi, Ed 10, Jakarta :EGC

Harley, P. 2002 Laboratory Exercises in Microbiology, $5^{\text {th }}$ edition, 257-260. New York: McGraw-Hill Companies.

Hastuti, R., T. 2008. Faktor-Faktor Risiko Ulkus Diabetika pada Penderita Diabetes Mellitus (Studi Kasus di RSUD Dr. Moewardi Surakarta). [Tesis]. Universitas Diponegoro, Semarang.

International Diabetes Federation (IDF). 2011. IDF Diabetes Atlas, $5^{\text {th }}$ Edition, International Diabetes Federation.

Jawetz., Melnick., dan Adelberg. 2010. Mikrobiologi Kedokteran. Jakarta: EGC.

Kemenkes RI. 2013. Riset Kesehatan Dasar. Badan Penelitian \& Pengembangan Kementrian Kesehatan RI, Jakarta.

Kontopoulou, K., Protonotariou, E., Vasilakos, K., Kriti, M., Koteli, A., Antoniadou, E., Safianou, D. 2010. Hospital Outbreak Caused By Klebsiella pneumonia Producing KPC-2 Betalactamase Resistant To Colistin. J Hosp Infect, 76(1) : 70-73

Lipsky, B., A., Berendt A., R., Cornia P., B., Pile, J., C., Peters, E., J., G., dan Armstrong, D., G. 2012. Infection Diseases Society of America Clinical Practice Guideline for the Diagnosis and Treatment of Diabetic Foot Infections, Clinical Infectious Diseases. 54 (12) : 132-173.

Ludden, C., Cormican, M., Vellinga, A., Johnson, J. R., Austin, B., dan Morris, D. 2015. Colonisation With ESBL - Producing
And Carbapenemase -Producing Enterobacteriaceae, Vancomycin - Resistant Enterococci, And Meticillin Resistant Staphylococcus Aureus In A Long-Tern Care Facility Over One Year. BMC Infect Dis. 15(168).

McPhee, S. J., dan Ganong, W. F. 2010. Patofisiologi Penyakit Pengantar Menuju Kedokteran Klinis, Edisi 5. Jakarta: EGC.

Nur, A., dan Marissa, N. 2016. Gambaran Bakteri Ulkus Diabetikum di Rumah Sakit Zainal Abidin dan Merauxa Tahun 2015, Buletin Penelitian Kesehatan. 44(3) : 187-196.

Patil, Y., Khadse, R., Chavan, S., dan Raut,S. 2018, Bacteriological Profil of Diabetic Foot Infections, European Journal of Pharmaceutical and Medical Research. 5 (6) : 631-635.

Riset Kesehatan Dasar (Riskesdas). 2013. Pedoman Pewancara Petugas Pengumpul Data, Badan Litbangkes Depkes RI, Jakarta.

Rizal. 2010. Microbial Pattern And Antimicrobial Resistance Of Isolates Collected From Various Specimen In DR. Oen Solo Baru Hospital, Sukoharjo, The Indonesian Journal Of Medical Science. 1(7) : 392.

Setianingsih, Y., Fadraersada, J., Ibrahim, A., dan Ramadhan, A. M. 2016. Pola Resistensi Bakteri Terhadap Antibiotik Pada Pasien Diabetic Foot Di RSUP Abdul Wahab Sjahranie Samarinda Periode Agustus-Oktober 2016, Prosiding Seminar Nasional Kefarmasian ke-4: 407-414.

Setiawan, D. S. 2010. Faktor Resiko Koloni sasi Enterobacteriaceae Pada Nasofaring Manusia Dewasa, Universitas Diponegoro, Semarang.

Suhartati, R., dan Faidah, E. N. 2014. Identifikasi Bakteri Oxacillin Resistant Staphylococcus Aureus (Orsa) Pada Ulkus Penderita Diabetes Mellitus Di Ruang Perawatan Bedah Rumah Sakit Umum Daerah (RSUD) Tasikmalaya, Jurnal Kesehatan Bakti Tunas Husada. 11 (1) : 161-167.

Waspadji, S. 2012. Komplikasi Kronik Diabetes: Mekanisme Terjadinya, Diagnosis \& Strategi Pengelolaan. Jakarta: EGC.

Yunir, Soebardi. 2006. Buku Ajar Ilmu Penyakit Dalam Jilid III Ed. 4. Jakarta: Balai penerbit FKU. 